\title{
GIS based Fertility Maps of Soils of Alirajpur District of Madhya Pradesh, India
}

\author{
Tikam Chand Yadav ${ }^{1}$, H.K. Rai ${ }^{1}$, G.S.Tagore ${ }^{1}$, Garima Padwar ${ }^{1}$, \\ Dayanidhi Chaubey $^{2}$ and Divya Bhayal $^{3}$
}

${ }^{1}$ Department of Soil Science and Agricultural Chemistry, Jawaharlal Nehru Krishi Vishwa

Vidhyalya, Jabalpur (M.P.) - 482 004, India

${ }^{2}$ Department of Agronomy, Bihar Agricultural University, Sabour (Bhagalpur) - 813210 , Bihar, India

${ }^{3}$ Department of Soil Science and Agricultural Chemistry, Indore (M.P.) - 452001, India

*Corresponding author

\section{A B S T R A C T}

Keywords

Fertility status, Soil maps, GIS, GPS, Alirajpur

\section{Article Info}

Accepted:

15 November 2018 Available Online:

10 December 2018
Geo-statistics is an important tools extensively used for analyzing the spatial variability, interpolating between point observations and ascertaining the interpolated values with specified error using a minimum number of observations. GPS based two hundred seventy two surface soil samples were collected randomly from agricultural area of Alirajpur district of Madhya Pradesh under AICRP on MSN project. Results recorded that the 73.90, 26.10, 77.57, 64.71, 93.01 and 25.37 per cent soil samples were found to be deficient in $\mathrm{N}$, $\mathrm{P}, \mathrm{K}, \mathrm{S}, \mathrm{Zn}$, and Fe respectively. Considering nutrient index values of $<1.67$ for low, 1.67 2.33 for medium and $>2.33$ for high fertility status, the soils of the study area were found to be in the category of low for OC, N, K,S and $\mathrm{Zn}$; medium for P; and high with $\mathrm{Mn}, \mathrm{Cu}$, Fe and B. From the study, it is concluded that the soils of tribal dominated Alirajpur district is deficient in many numbers of nutrients. Therefore balanced and soil test based nutrient management practices should be followed to alleviate nutrient deficiencies of soils for sustainable crop production. None of the soil samples were tested low in $\mathrm{Cu}$ and $\mathrm{Mn}$ were found to be deficient. GIS based fertility maps showed that the fertility status of N, P, $\mathrm{K}, \mathrm{S}, \mathrm{Zn}$, and Fe were deficient in major areas of research. Thus, these maps are useful for recommendation of fertilizers to increase the productivity.

\section{Introduction}

Soil characterization is an important aspect in view of sustainability (Singh et al., 2017). Both macro- as well as micro- nutrients, play a vital role to govern the fertility of soil and control the productivity of crops (Bharti et al.,
2017). Currently, crop productivity is declining or stagnating because of imbalanced and inadequate fertilizers application coupled with low efficiency of other inputs mostly in the tribal belt of the country. Also, response efficiency of chemical fertilizer nutrients has declined tremendously under an intensive 
agriculture system in recent years (Meena $e t$ al., 2017). Intensive cultivation and indiscriminate use of high analysis chemical fertilizers results in deficiency of micronutrients (Singh et al., 2007). Application of nutrients based on requirements for optimum production at each location because there is high spatial variability of macro-nutrients within individual fields (Ruffo et al., 2005). Thus, information on spatial variability of soil nutrients is important for sustainable management of soil fertility (Fraisse et al., 1999). In this context, it is necessary to evaluate the fertility status of the soil and to promote the recommendations of soil test for balanced nutrition to maintain soil health due to the randomness of variations from one place to another. Geo-statistics has been used extensively to characterize the spatial variability of soil attributes (Cambule et al., 2014). Farmers of Alirajpur district have very little knowledge of fertility status of area is limited; therefore, the desired level of productivity is not being achieved even after utilizing all inputs. Hence, the present study was carried out in the limited area. Understanding of spatial variability and distribution of soil properties is critical for the farmer attempting to increase nutrients use efficiency and crop productivity. Application of fertilizers on the basis of soil characteristics associated with fertilizers recommendation may aid in minimizing the fertilizers input without any yield loss. Geo-statistics is an applied tools extensively used for analyzing the spatial variability, interpolating between point observations and ascertaining the interpolated values with specified error using a minimum number of observations (Long et al., 2014 and Cambule et al., 2014). The information about spatial variability in physical, chemical and biochemical properties as well as microbiological processes of soil had great importance in the selection of crops and cropping system and also broad extent the ideas about prevailing management practices (Weindorf and Zhu, 2010; Cao et al., 2011 and Liu et al., 2013). Spatial variability in $\mathrm{pH}$, soil organic matter, total and available NPK as well as micro-nutrients have been studied by many researchers under contrasting soil and management systems to refine and implement the site-specific nutrient management (Franzen et al., 2002 and Li et al., 2011).

Soil is one of the key components of the sustainable agricultural production system and its quality is governed by physico-chemical characteristics and nutrient supplying capacity which ultimately reflected through crop productivity. Soil quality was defined as the capacity of specific kind of soil to function, within the ecosystem and land use boundaries, to sustain productivity, maintain environmental quality and promote plant growth as well as human health (Andrews et al., 2001). The concept of soil quality was introduced for proper stratification and allotment of agricultural inputs (Warkentin and Fletcher, 1977). Soils are inherently heterogeneous in nature because many factors contribute its formation and the complex interactions of these factors (Maniyunda et al., 2013). Characterizing spatial variability of soil nutrients in relation to site properties, including climate, land use, landscape position, and other variables, is important for understanding how ecosystems work and assessing the effects of future land use change on soil nutrients (Wang et al., 2001). It is well established that a change in land use, longterm intensive cultivation and chemical mineral fertilization can cause significant variations in soil properties (Jha and Mohapatra, 2010). The nature and characteristics of the soils are mainly dependent on geological formations, topography, and climate of the region in which the soil occurs. Dokuchaev who considered the soils to be as independent natural body each with a unique morphology resulting from 
the unique combination of climate, living matter, parent materials, relief and age of landform.

\section{Materials and Methods}

\section{Description of study area}

Geographically, the Alirajpur district is situated $22^{\circ} 18^{\prime} 19^{\prime \prime}$ latitude and $74^{\circ} 21^{\prime} 09^{\prime \prime}$ longitude and at an altitude of $315 \mathrm{~m}$ above mean sea level. Administratively, district covers an area of $2165 \mathrm{~km}^{2}$ and divided into six blocks name as Bhabara, Jobat, Sondwa, Kathiwara, Alirajpur and Udaigarh. Location and sampling site maps of study area is given in Figure 1.

\section{Soil sampling and their processing}

GPS based two hundred seventy two surface soil samples were collected across all the blocks of Alirajpur district of Madhya Pradesh (India). Composite soil sample was collected and kept into properly labeled sample cloth bags. Soil samples were brought to the laboratory and air dried, crushed with wooden pestle and mortar, sieved through $2 \mathrm{~mm}$ stainless steel sieve.

\section{Laboratory analysis}

Soil $\mathrm{pH}$, electrical conductivity (EC), soil organic carbon, and calcium carbonate was determined using standard procedure described by Jackson (1973). Available N was determined as per the method is given by Subbiah and Asija (1956). Available P was determined by $0.5 \mathrm{M}$ sodium bicarbonate procedure as described by Olsen et al., (1954) using Spectrophotometer. Available $\mathrm{K}$ was extracted with $1 \mathrm{~N} \quad \mathrm{NH}_{4} \mathrm{OAc}$ and then measured by Flame Photometer (Jackson, 1973). The available sulphur was extracted by $0.15 \% \mathrm{CaCl}_{2}$ solution and the concentration of sulphur was determined by the turbidimetric method using spectrophotometer (Chesnin and Yien, 1951). Available micro-nutrients were extracted by DTPA-CaCl ${ }_{2}$ solution and analyzed using atomic absorption spectrophotometer (Lindsay and Norvell, 1978). Hot water soluble boron in soil was analyzed by azomethine- $\mathrm{H}$ method as outlined by Berger and Truog (1939). The nutrient index (NI) values for available nutrients present in the soils was calculated utilizing the formula suggested by Parker et al., (1951) and classified this index as low $(<1.67)$, medium (1.67 to 2.33) and high (>2.33).

\section{Fertility maps prepared}

Spatial correlation structure of available nutrients in the soil and spatially estimates their values at unsampled locations using geostatistical tool in GIS 9.3.1 software.

\section{Descriptive statistics of soil properties}

Data presented in table 1 the mean values for $\mathrm{pH}, \mathrm{EC}, \mathrm{SOC}$ and $\mathrm{CaCO}_{3}$ content 6.53, 0.09 $\mathrm{dS} \mathrm{m} \mathrm{m}^{-1}, 5.20 \mathrm{~g} \mathrm{~kg}^{-1}$ and $34.82 \mathrm{~g} \mathrm{~kg}^{-1}$ with a range of 4.70 to $8.40,0.03$ to $0.90 \mathrm{dS} \mathrm{m}^{-1}, 0.47$ to $12.92 \mathrm{~g} \mathrm{~kg}^{-1}$ and 5.0 to $115 \mathrm{~g} \mathrm{~kg}^{-1}$, respectively. The available $\mathrm{N}, \mathrm{P}, \mathrm{K}$, and $\mathrm{S}$ content in soils of Alirajpur district ranged from 76.0 to $382.0 \mathrm{~kg} \mathrm{ha}^{-1}, 1.34$ to $62.13 \mathrm{~kg}$ $\mathrm{ha}^{-1}, 53.52$ to $529.85 \mathrm{~kg} \mathrm{ha}^{-1}$ and 0.55 to 33.90 $\mathrm{mg} \mathrm{kg}{ }^{-1}$ with mean value of $186.36 \mathrm{~kg} \mathrm{ha}^{-1}$, $21.01 \mathrm{~kg} \mathrm{ha}^{-1}, 201.39 \mathrm{~kg} \mathrm{ha}^{-1}$ and $8.99 \mathrm{mg} \mathrm{kg}^{-1}$, respectively. Fraction of $\mathrm{Zn}, \mathrm{Cu}, \mathrm{Fe}, \mathrm{Mn}$, and B contents in the soil varied from 0.03 to 1.98 , 0.06 to $3.74,1.07$ to $36.0,1.34$ to 43.0 and 0.03 to $4.76 \mathrm{mg} \mathrm{kg}^{-1}$ with mean values of 0.30 , 0.96, 9.92, 14.54 and $1.67 \mathrm{mg} \mathrm{kg}$, respectively.

According Hillel (1980) and Yang and Yang (2005), there are three classes about coefficient of variation (C.V.) of soil nutrients, weak variation $(\mathrm{C} . \mathrm{V} .=<0.1)$, medium variation $(\mathrm{C} . \mathrm{V} .=0.1-1.0)$, strong variation 
(C.V. $=>1.0)$. The EC had the largest variation $(\mathrm{CV}=88.91 \%)$ followed by $\mathrm{Cu}(\mathrm{CV}$ $=83.26 \%$ ) while, $\mathrm{pH}$ was found least variable $(\mathrm{CV}=13.49 \%)$. Coefficient of variation less than $10 \%, 10$ to $100 \%$, and more than $100 \%$ was considered as low, moderate, and high variability, respectively. The $\mathrm{pH}$ had least variability $(\mathrm{CV}=13.49 \%)$, while $\mathrm{CaCO}_{3}$ and SOC had moderate variability $(\mathrm{CV}=54.24$ and $60.32 \%$, respectively. Macronutrients were found moderately variable which ranged from 39.85 to 77.79 per cent. Micronutrients were also found moderately variable which ranged from 68.80 to 83.26 per cent in Alirajpur district as a whole. The available $\mathrm{K}$ in soil had lowest variability $(\mathrm{CV}=39.85 \%)$ followed by available N (43.68 \%), available $\mathrm{P}(69.80 \%)$, and $\mathrm{S}$ had the highest variability (77.79\%). Among the micronutrients, $\mathrm{Cu}$ was found highly variable $(\mathrm{CV}=83.26 \%)$ followed by $\mathrm{Zn}(79.09 \%), \mathrm{Fe}(73.85 \%)$ and Mn (70.45 \%) and lowest in B (68.80\%). Overall $\mathrm{pH}$ had low variability where as other soil properties showed moderate variability.

\section{Fertility status}

As per Subbiah and Asija (1956), the available $\mathrm{N}$ was found to be low $(73.90 \%)$ and medium $(26.10 \%)$ in soil samples. It may be due low organic matter content of soil as well as rapid loss of applied $\mathrm{N}$ in soil. On the basis of the limits suggested by Muhr et al., (1963), the available phosphorus content was found to be low $(26.10 \%)$, medium $(34.56 \%)$ and high $(39.34 \%)$ in the soil samples. The low amount of available $\mathrm{P}$ may be due to application of lower doses of $\mathrm{P}$ fertilizers, fixation of $\mathrm{P}$ on clay minerals or $\mathrm{CaCO}_{3}$ surfaces with the time elapsed between fertilizer application and crop nutrients uptake. It may also be due low organic matter content of soil (Sanyal et al., 2015) (Table 2).

According to Muhr et al., (1963), the available potassium content was found to be low
$(77.57 \%)$ in the soil samples, high in $1.84 \%$ soil samples and $20.59 \%$ of soil samples were found in medium. For these, soils available micro-nutrients status using critical limit as given in table 4 for DTPA-extractable $\mathrm{Zn}$ content was found to be deficient in $93.01 \%$, medium in $5.88 \%$ and high in $1.10 \%$ soil samples. The data showed the DTPA extractable Fe content was found medium in $31.99 \%$ soil samples and none of the soil samples were tested low in $\mathrm{Cu}, \mathrm{Fe}, \mathrm{Mn}$, and $\mathrm{B}$ content, respectively. All soil samples were found sufficient in case of $\mathrm{Cu}$ content. The present study result was supported by Athokpam et al., (2013).

\section{Physico-chemical properties of soils in different blocks of Alirajpur district}

Data pertaining to variation in physicochemical properties of soil of Alirajpur, Bhabra, Jobat, Kathiwara, Sondwa and Udaigarh blocks of Alirajpur district are presented in table 3 . The values in the soil $\mathrm{pH}$ of Alirajpur, Bhabra, Jobat, Kathiwara, Sondwa, and Udaigarh blocks of soil samples varied from 4.90 to $8.20,5.20$ to $7.20,4.78$ to $8.00,5.00$ to $8.40,5.60$ to 8.10 and 4.70 to 7.90 with mean value of $6.53,6.22,6.75,5.82$, 7.08 and 6.33; EC varied from 0.03 to $0.43 \mathrm{dS}$ $\mathrm{m}^{-1}, 0.04$ to $0.13 \mathrm{dS} \mathrm{m}^{-1}, 0.03$ to $0.65 \mathrm{dS} \mathrm{m}^{-1}$, 0.03 to $0.35 \mathrm{dS} \mathrm{m}^{-1}, 0.04$ to $0.90 \mathrm{dS} \mathrm{m}^{-1}$ and 0.04 to $0.32 \mathrm{dS} \mathrm{m}^{-1}$ with mean value of 0.09 , $0.08,0.09,0.06,0.13$ and $0.09 \mathrm{dS} \mathrm{m}^{-1}$; further SOC varied from 0.55 to $12.92 \mathrm{~g} \mathrm{~kg}^{-1}, 1.53$ to $12.07 \mathrm{~g} \mathrm{~kg}^{-1}, 0.51$ to $11.89 \mathrm{~g} \mathrm{~kg}^{-1}, 0.47$ to 8.45 $\mathrm{g} \mathrm{kg}^{-1}, 0.51$ to $12.91 \mathrm{~g} \mathrm{~kg}^{-1}$ and 1.20 to $12.12 \mathrm{~g}$ $\mathrm{kg}^{-1}$ with mean value of $4.58,5.60,4.89,3.24$, 7.27 and $6.37 \mathrm{~g} \mathrm{~kg}^{-1}$ and $\mathrm{CaCO}_{3}$ varied from 10.00 to $115.00 \mathrm{~g} \mathrm{~kg}^{-1}, 20.00$ to $100.00 \mathrm{~g} \mathrm{~kg}^{-1}$, 5.00 to $90.00 \mathrm{~g} \mathrm{~kg}^{-1}, 10.00$ to $50.00 \mathrm{~g} \mathrm{~kg}^{-1}$, 5.00 to $100.00 \mathrm{~g} \mathrm{~kg}^{-1}$ and 15.00 to $115.00 \mathrm{~g}$ $\mathrm{kg}^{-1}$ and $40.66 \mathrm{~g} \mathrm{~kg}^{-1}$ with mean value of $30.66,37.00,32.44,26.83,47.16$ and $40.66 \mathrm{~g}$ $\mathrm{kg}^{-1}$, respectively. 


\section{Macro-nutrient status}

Available nitrogen content in the soils of Alirajpur, Bhabra, Jobat, Kathiwara, Sondwa and Udaigarh blocks ranged from 78 to 382 , 93 to 355,78 to 342,76 to 27,87 to 356 and 90 to $350 \mathrm{~kg} \mathrm{ha}^{-1}$ with the mean values of $170.9,201.8,177.71,138.63,237.84$ and $212.53 \mathrm{~kg} \mathrm{ha}^{-1}$, respectively. It was also found that variability in available $\mathrm{N}$ content in the soil of Alirajpur, Bhabra, Jobat, Kathiwara, Sondwa and Udaigarh blocks was 48.23, $31.34,38.66,39.74,36.77$ and 40.54 per cent respectively.

About 81.93 and 18.07, 75 and 25, 80.95 and $19.05,93.33$ and $6.67,47.37$ and 52.63 and 55.26 and 44.74 soil samples were rated to be low and medium, respectively indicating nutrient index value of 1.18, 1.25, 1.19, 1.07, 153 and 1.45 in the soils of Alirajpur, Bhabra, Jobat, Kathiwara, Sondwa and Udaigarh blocks. Available P content in the soils of Alirajpur, Bhabra, Jobat, Kathiwara, Sondwa and Udaigarh blocks was ranged from 1.67 to $59.11,6.91$ to $59.61,1.45$ to $49.92,1.34$ to $59.11,1.60$ to 62.13 and 1.34 to $59.61 \mathrm{~kg} \mathrm{ha}^{-1}$ with a mean of $21.21,31.77,16.77,15.65$, 27.43 and $19.73 \mathrm{~kg} \mathrm{ha}^{-1}$, respectively. It was also found that variability in available $\mathrm{P}$ in the soil of Alirajpur, Bhabra, Jobat, Kathiwara, Sondwa and Udaigarh blocks was 67.32, $53.86,67.24,82.25,63.87$ and 64.53 per cent respectively. About 24.10, 36.14 and 39.76; 10,15 and $75 ; 33.33,41.27$ and $25.40 ; 43.33$; 30 and 26.67, 15.79; 31.58 and 52.63, 23.68; 36.84 and 39.47 per cent samples drawn from Alirajpur, Bhabra, Jobat, Kathiwara, Sondwa and Udaigarh blocks were observed low, medium and high, respectively. Soil samples were observed to be medium and high indicating nutrient index value of 2.16, 2.65, 1.92, 1.83, 2.37 and 2.16 of Alirajpur, Bhabra, Jobat, Kathiwara, Sondwa and Udaigarh blocks. Available K content in the soils of Alirajpur, Bhabra, Jobat, Kathiwara, Sondwa and Udaigarh blocks was ranged from 56.91 to $398,76.06$ to $336.83,63.67$ to $383.04,53.52$ to $505.88,56.91$ to 337.96 and 62.54 to 529.85 $\mathrm{kg} \mathrm{ha}^{-1}$ with a mean of $189.73,203.03,216.03$, $236.78, \quad 171.93$ and $203.28 \mathrm{~kg} \mathrm{ha}{ }^{-1}$, respectively. It was also found that variability in available $\mathrm{P}$ in the soil of Alirajpur, Bhabra, Jobat, Kathiwara, Sondwa and Udaigarh blocks was 35.40, 36.06, 33.38, 53.84, 31.40 and 42.54 per cent. About 70, 16.67 and 13.33; and 78.95, 18.95 and 2.63 per cent soil samples were found low, medium and high, respectively, indicating nutrient index of 1.43 and 1.24 in the soil of Kathiwara and Udaigarh blocks. However, in Alirajpur, Bhabra, Jobat and Sondwa blocks the nutrient index of 1.20, 1.25, 1.33 and 1.03 i.e. medium, showing, respectively. About 79.52 and 20.48, 75 and 25, 66.67 and 33.33 and 97.37 and 2.63 per cent samples were low and medium, respectively. Available sulphur (S) content in soils of Alirajpur, Bhabra, Jobat, Kathiwara, Sondwa and Udaigarh blocks was ranged from 0.55 to $31.09,1.10$ to $3109,0.82$ to 32.14 , 0.82 to $33.90,0.82$ to 28.00 and 0.82 to 18.20 $\mathrm{mg} \mathrm{kg}{ }^{-1}$ with a mean of $7.21,10.08,10.12$, $9.79,10.62$ and $8.16 \mathrm{mg} \mathrm{kg}^{-1}$, respectively. It was also found that variability in available $P$ in soil of Alirajpur, Bhabra, Jobat, Kathiwara, Sondwa and Udaigarh blocks was 89.65, $76.61,59.29,97.25,77.58$ and 57.15 per cent. About 75.90, 20.48 and 3.61; 55, 35 and 10; 55.56, 41.27 and 3.17; 66.67, 20 and 13.33 and 55.26, 28.95 and 15.79 per cent samples drawn from Alirajpur, Bhabra, Jobat, Kathiwara and Sondwa blocks were observed low, medium and high, respectively. Soil samples were observed to be medium and high indicating nutrient index value of $1.28,1.55$, $1.48,1.47$ and 1.61 of Alirajpur, Bhabra, Jobat, Kathiwara, Sondwa and Udaigarh blocks. About 68.42 and 31.58 soil samples were rated to be low and medium, respectively indicating nutrient index value of 1.32 in only soils of Udaigarh block. 


\section{Micro-nutrient status}

The DTPA extractable Zn content in soils of Alirajpur, Bhabra, Jobat, Kathiwara, Sondwa and Udaigarh blocks varied from 0.03 to 0.97 , 0.17 to $1.97,0.04$ to $1.50,0.05$ to $1.13,0.08$ to 1.98 and 0.04 to $1.03 \mathrm{mg} \mathrm{kg}^{-1}$ with a mean value of $0.27,0.50,0.27,0.25,0.29$ and 0.34 $\mathrm{mg} \mathrm{kg}^{-1}$, respectively. It was moderately variable by showing 51.81, 76.74, 78.88, $90.24,108.72$ and 61.99 per cent variability in respective blocks. In soils of Bhabra, Jobat and Sondwa block about 75.00, 20 and 5; 95.24, 3.17 and 1.57; and 94.74, 2.63 and 2.63 per cent soils samples were rated to be low, medium and high, respectively. Nutrient index of $\mathrm{Zn}$ was also calculated to be $1.30,1.06$ and 1.08 i.e. medium, high and high respectively. However, 96.39 and 3.61; 93.33 and 6.67; 89.47 and 10.53 per cent samples were found medium and high in the soils of Alirajpur, Kathiwara and Udaigarh blocks respectively indicating high nutrient index $(1.04,1.07$ and 1.11). The DTPA extractable $\mathrm{Cu}$ content varied from 0.09 to $3.74,0.59$ to $3.15,0.16$ to $3.16,0.06$ to $2.55,0.18$ to3.42 and 0.06 to 3.36 $\mathrm{mg} \mathrm{kg}{ }^{-1}$ with a mean value of $0.96,1.27,0.85$, $0.48,0.95$ and $1.40 \mathrm{mg} \mathrm{kg}^{-1}$ in the soils of Alirajpur, Bhabra, Jobat, Kathiwara, Sondwa and Udaigarh blocks, respectively. Variability in available $\mathrm{Cu}$ in soils of above respective blocks was 95.56, 47.58, 81.93, 102.74, 76.67, and 58.99 per cent. None of soil samples were found to be deficient in the soils of all Blocks. The Fe content ranged from 1.55 to 25.54 , 3.65 to $30.00,1.43$ to $36.00,1.07$ to 21.90 , 1.33 to 16.15 and 1.48 to $34.55 \mathrm{mg} \mathrm{kg}^{-1}$ with a mean value of $7.55,19.53,9.20,11.56,6.04$ and $13.79 \mathrm{mg} \mathrm{kg}^{-1}$ in the soils of Alirajpur, Bhabra, Jobat, Kathiwara, Sondwa and Udaigarh blocks, respectively. Available $\mathrm{Cu}$ had 65.20, 43.31, 75.83, 45.98, 65.11 and 67.55 per cent variability in above respective blocks. In Alirajpur, Bhabra, Jobat, Kathiwara, Sondwa and Udaigarh blocks about 32.53, 39.76 and $27.71 ; 1.20,1.20$ and $90.00 ; 25.40$,
36.51 and 38.10; $10.00,20.00$ and 70.00; $47.37,28.95$ and 23.68 and $10.53,34.21$ and 55.26 per cent soil samples were rated as low, medium and high, respectively. Nutrient index of $\mathrm{Fe}$ was found to be $1.95,2.58,2.13,2.60$, 1.76 and 2.45 i.e. low, medium, and high, respectively.

The DTPA extractable Mn content in the soil samples varied from 1.34 to $42.00,4.58$ to $43.00,2.49$ to $38.94,2.43$ to $38.79,1.97$ to 35.85 , and 1.73 to $43.00 \mathrm{mg} \mathrm{kg}^{-1}$ with average values of 12.34, 26.64, 12.17, 18.32, 10.02 and $18.43 \mathrm{mg} \mathrm{kg}^{-1}$ in Alirajpur, Bhabra, Jobat, Kathiwara, Sondwa and Udaigarh blocks, respectively. Variability in available $\mathrm{Mn}$ in the soil was $71.05,45.35,67.56,52.21,85.19$ and 58.80 per cent in above respective blocks. In Alirajpur, Jobat, Kathiwara, Sondwa and Udaigarh blocks, about 8.43 and $91.57 ; 6.35$ and $93.65 ; 3.33$ and $96.67 ; 23.68$ and 76.32 and 5.26 and 94.74 per cent soils samples were found medium and high, respectively. NI indicated that the Mn status was found to be high in the soil of the all blocks.

\section{Hot water soluble boron in soil}

The hot water soluble B content in the soil varied from 0.03 to $4.43,0.45$ to $2.88,0.05$ to $4.76,0.69$ to $4.43,0.64$ to 3.64 and 0.05 to $3.85 \mathrm{mg} \mathrm{kg}^{-1}$ with mean values of $1.91,1.42$, $1.02,2.41,2.07$ and $1.36 \mathrm{mg} \mathrm{kg}^{-1}$ in Alirajpur, Bhabra, Jobat, Kathiwara, Sondwa and Udaigarh blocks, respectively. It was moderately variable to the extent of 60.85 , $60.25,106.17,44.29,37.60$ and 81.79 per cent in the soil samples of above respective blocks. In Alirajpur, Bhabra, Jobat, and Udaigarh blocks $18.07,8.43$ and $73.49 ; 1.20,10.84$ and $50.00 ; 47.62,20.63$ and 31.75 and 23.68, 23.68 and 52.63 per cent soils samples were found low, medium and high, respectively. The NI of soils in above respective blocks was found to the tune of 2.55, 2.45, 1.84 and 2.29 which was high. However, 3.33 and 96.67 and 
7.89 and 92.11 per cent samples were noted medium and high, respectively indicating nutrient index of 2.97and 2.92 (high) in the soil of Kathiwara and Sondwa blocks.

\section{Physico-chemical properties of soils}

Results pertaining to physico-chemical properties of soils of Alirajpur district showed that the soil $\mathrm{pH}$ of Alirajpur district as whole, varied from 4.7 to 8.4 with mean value of 6.5 in different blocks. Variation in soil $\mathrm{pH}$ under different blocks and district as whole might be due to variations in parent material of soil, management practices and land uses. Similar variations in soil $\mathrm{pH}$ under different regions were also reported by Raghuvanshi et al., (1992); Dubliya (2011); Singh et al., (2014) and Baishya and Sharma (2017).

However, electrical conductivity of soils across different blocks of Alirajpur district ranged from 0.03 to $0.90 \mathrm{dS} \mathrm{m}^{-1}$ at $25^{\circ} \mathrm{C}$ with average of $0.09 \mathrm{dS} \mathrm{m}^{-1}$ which was in normal range $\left(<1 \mathrm{dS} \mathrm{m}^{-1}\right.$ at $\left.25^{\circ} \mathrm{C}\right)$. The low electrical conductivity in soil under study area might be due to high rainfall received and deep water table. Similar results for different soils were also reported by Tomar (1968); Singh (2012); Dilliwar et al., (2014) and Singh et al., (2014).

Whereas, organic carbon in the soil of different blocks of Alirajpur district was varied from 0.47 to $12.92 \mathrm{~g} \mathrm{~kg}^{-1}$ with mean values ranged from 3.24 to $7.27 \mathrm{~g} \mathrm{~kg}^{-1}$, while for Alirajpur district as whole SOC varied from 0.47 to $12.92 \mathrm{~g} \mathrm{~kg}^{-1}$ with average value of $5.2 \mathrm{~g} \mathrm{~kg}^{-1}$. Variation in organic carbon content in the soil samples was may be due to variation in land use pattern, addition of organic matter in soil. Mandal et al., (2011) also found that crop species and cropping systems may play an important role for variations in soil organic carbon. Findings of Singh et al., (2014) and Yang et al., (2014) also support the results of the present study.
Calcium carbonate content in the soil of different blocks of Alirajpur district ranged from 5 to $115 \mathrm{~g} \mathrm{~kg}^{-1}$ with average values varied from 26.83 to $47.16 \mathrm{~g} \mathrm{~kg}^{-1}$. Results also indicated that lowest and the highest values of $\mathrm{CaCO}_{3}$ in the soil were obtained in Sondwa and Udaigarh blocks, respectively might be due to calcareous parent materials and lower leaching process. Similar results were reported by Dilliwar et al., (2014) and Singh et al., (2014).

Status and spatial distribution of macronutrients in the soil of different block of Alirajpur district

Results partaining to status of macro-nutrients in the soil of different blocks of Alirajpur district showed that the contents of available $\mathrm{N}, \mathrm{P}, \mathrm{K}$ and $\mathrm{S}$ in soils of different blocks varied from 76 to $382,1.34$ to $62.13,53.52$ to $529.85 \mathrm{~kg} \mathrm{ha}^{-1}$ and 0.55 to $33.90 \mathrm{mg} \mathrm{kg}^{-1}$ with mean values of $186.36,21.01,201.39 \mathrm{~kg} \mathrm{ha}^{-1}$ and $8.99 \mathrm{mg} \mathrm{kg}^{-1}$, respectively. Results also showed that available $\mathrm{P}, \mathrm{K}$ and $\mathrm{S}$ in the soil were moderately variable and available $\mathrm{N}$ in soil was less variable in terms of coefficient of variation across different blocks of Alirajpur district. Maniyunda et al., (2013); Ravikumar and Somashekar (2014) and Olorunlana (2015) also reported similar findings. However, Denton et al., (2017) reported high variability in available phosphorus and potassium $(\mathrm{C} . \mathrm{V}=>35 \%)$ but moderate variability in available $\mathrm{N}, \mathrm{CEC}$ and $\mathrm{SOC}$ and less variability in $\mathrm{pH}(\mathrm{C} . \mathrm{V}=<15 \%)$.

Results also revealed that deficiency of N, P, $\mathrm{K}$, and $\mathrm{S}$ in the soil of Alirajpur district as whole was found to the extent of 73.9, 26.1, 77.6 and 64.7 per cent in the soil samples, and 26.1, 34.6, 20.6 and 29.0 per cent soil samples were found medium, respectively. Whereas, 39.34, 1.84 and 6.25 per cent soil samples were analyzed high in $\mathrm{P}, \mathrm{K}$ and $\mathrm{S}$ status, 
respectively. Nutrient index (NI) was found to be $1.26,2.13,1.24$ and 1.42 for $\mathrm{N}, \mathrm{P}, \mathrm{K}$ and $\mathrm{S}$, respectively. The categories of the soil fertility status were made with respect to $\mathrm{N}, \mathrm{P}$,
$\mathrm{K}$ and $\mathrm{S}$ as medium high medium and low. Kumar et al., (2014) and Ravikumar and Somashekar (2014) also closely reported similar findings.

Table.1 Descriptive statistics of formulations $(\mathrm{n}=272)$

\begin{tabular}{|c|c|c|c|c|c|}
\hline Parameters & Min & Max & Mean & SD & CV (\%) \\
\hline $\mathbf{p H}$ & 4.70 & 8.40 & 6.53 & 0.88 & 13.49 \\
\hline $\mathbf{E C}$ & 0.03 & 0.90 & 0.09 & 0.08 & 88.91 \\
\hline $\mathbf{O C}$ & 0.47 & 12.92 & 5.20 & 3.14 & 60.32 \\
\hline $\mathbf{C a C O}_{\mathbf{3}}$ & 5.00 & 115.00 & 34.82 & 18.89 & 54.24 \\
\hline $\mathbf{N}$ & 76.00 & 382.00 & 186.36 & 81.40 & 43.68 \\
\hline $\mathbf{P}$ & 1.34 & 62.13 & 21.01 & 14.66 & 69.80 \\
\hline $\mathbf{K}$ & 53.52 & 529.85 & 201.39 & 80.26 & 39.85 \\
\hline $\mathbf{S}$ & 0.55 & 33.90 & 8.99 & 6.99 & 77.79 \\
\hline $\mathbf{Z n}$ & 0.03 & 1.98 & 0.30 & 0.23 & 79.09 \\
\hline $\mathbf{C u}$ & 0.06 & 3.74 & 0.96 & 0.80 & 83.26 \\
\hline $\mathbf{F e}$ & 1.07 & 36.00 & 9.92 & 7.32 & 73.85 \\
\hline $\mathbf{M n}$ & 1.34 & 43.00 & 14.54 & 10.24 & 70.45 \\
\hline $\mathbf{B}$ & 0.03 & 4.76 & 1.67 & 1.15 & 68.80 \\
\hline
\end{tabular}

Table.2 Fertility status and NI of soils of Alirajpur district $(\mathrm{n}=272)$

\begin{tabular}{|c|c|c|c|c|}
\hline Parameters & Low & Medium & High & NI \\
\hline $\mathbf{N}$ & 73.90 & 26.10 & 0.00 & 1.26 \\
\hline $\mathbf{P}$ & 26.10 & 34.56 & 39.34 & 2.13 \\
\hline $\mathbf{K}$ & 77.57 & 20.59 & 1.84 & 1.24 \\
\hline $\mathbf{S}$ & 64.71 & 29.04 & 6.25 & 1.42 \\
\hline $\mathbf{Z n}$ & 93.01 & 5.88 & 1.10 & 1.08 \\
\hline $\mathbf{C u}$ & 7.35 & 23.90 & 68.75 & 2.61 \\
\hline $\mathbf{F e}$ & 25.37 & 31.99 & 42.65 & 2.17 \\
\hline $\mathbf{M n}$ & 0.00 & 8.46 & 91.54 & 2.92 \\
\hline $\mathbf{B}$ & 20.22 & 15.44 & 64.34 & 2.44 \\
\hline
\end{tabular}


Table.3 Status of physico-chemical properties of soils of different blocks of Alirajpur district

\begin{tabular}{|c|c|c|c|c|c|c|c|c|c|c|}
\hline & & Min & $\operatorname{Max}$ & Mean & $\mathrm{SD}$ & $\mathrm{CV}$ & PSD & PSM & PSH & $\mathrm{NI}$ \\
\hline \multirow[t]{4}{*}{ Alirajpur $(n=83)$} & $\mathbf{N}$ & 78.00 & 382.00 & 170.90 & 82.42 & 48.23 & 81.93 & 18.07 & 0.00 & 1.18 \\
\hline & $\mathbf{P}$ & 1.67 & 59.11 & 21.21 & 14.28 & 67.32 & 24.10 & 36.14 & 39.76 & 2.16 \\
\hline & $\mathbf{K}$ & 56.91 & 398.00 & 189.73 & 67.17 & 35.40 & 79.52 & 20.48 & 0.00 & 1.20 \\
\hline & $\mathbf{S}$ & 0.55 & 31.09 & 7.21 & 6.46 & 89.65 & 75.90 & 20.48 & 3.61 & 1.28 \\
\hline \multirow[t]{4}{*}{ Bhabra $(n=20)$} & $\mathbf{N}$ & 93.00 & 355.00 & 201.80 & 63.25 & 31.34 & 75.00 & 25.00 & 0.00 & 1.25 \\
\hline & $\mathbf{P}$ & 6.91 & 59.61 & 31.77 & 17.11 & 53.86 & 10.00 & 15.00 & 75.00 & 2.65 \\
\hline & $\mathbf{K}$ & 76.06 & 336.83 & 203.03 & 73.21 & 36.06 & 75.00 & 25.00 & 0.00 & 1.25 \\
\hline & $\mathbf{S}$ & 1.10 & 31.09 & 10.08 & 7.73 & 76.61 & 55.00 & 35.00 & 10.00 & 1.55 \\
\hline \multirow[t]{4}{*}{ Jobat $(n=63)$} & $\mathbf{N}$ & 78.00 & 342.00 & 177.71 & 68.70 & 38.66 & 80.95 & 19.05 & 0.00 & 1.19 \\
\hline & $\mathbf{P}$ & 1.45 & 49.92 & 16.77 & 11.28 & 67.24 & 33.33 & 41.27 & 25.40 & 1.92 \\
\hline & $\mathbf{K}$ & 63.67 & 383.04 & 216.03 & 72.12 & 33.38 & 66.67 & 33.33 & 0.00 & 1.33 \\
\hline & $\mathbf{S}$ & 0.82 & 32.14 & 10.12 & 6.00 & 59.29 & 55.56 & 41.27 & 3.17 & 1.48 \\
\hline \multirow[t]{4}{*}{ Kathiwara $(n=30)$} & $\mathbf{N}$ & 76.00 & 278.00 & 138.63 & 55.10 & 39.74 & 93.33 & 6.67 & 0.00 & 1.07 \\
\hline & $\mathbf{P}$ & 1.34 & 59.11 & 15.65 & 12.87 & 82.25 & 43.33 & 30.00 & 26.67 & 1.83 \\
\hline & $\mathbf{K}$ & 53.52 & 505.88 & 236.78 & 127.49 & 53.84 & 70.00 & 16.67 & 13.33 & 1.43 \\
\hline & $\mathbf{S}$ & 0.82 & 33.90 & 9.79 & 9.53 & 97.25 & 66.67 & 20.00 & 13.33 & 1.47 \\
\hline \multirow[t]{4}{*}{ Sondwa $(\mathrm{n}=38)$} & $\mathbf{N}$ & 87.00 & 356.00 & 237.84 & 87.45 & 36.77 & 47.37 & 52.63 & 0.00 & 1.53 \\
\hline & $\mathbf{P}$ & 1.60 & 62.13 & 27.43 & 17.52 & 63.87 & 15.79 & 31.58 & 52.63 & 2.37 \\
\hline & $\mathbf{K}$ & 56.91 & 337.96 & 171.93 & 53.99 & 31.40 & 97.37 & 2.63 & 0.00 & 1.03 \\
\hline & $\mathbf{S}$ & 0.82 & 28.00 & 10.62 & 8.24 & 77.58 & 55.26 & 28.95 & 15.79 & 1.61 \\
\hline \multirow[t]{4}{*}{ Udaigarh $(\mathrm{n}=38)$} & $\mathbf{N}$ & 90.00 & 350.00 & 212.53 & 86.17 & 40.54 & 55.26 & 44.74 & 0.00 & 1.45 \\
\hline & $\mathbf{P}$ & 1.34 & 59.61 & 19.73 & 12.73 & 64.53 & 23.68 & 36.84 & 39.47 & 2.16 \\
\hline & $\mathbf{K}$ & 62.54 & 529.85 & 203.28 & 86.47 & 42.54 & 78.95 & 18.42 & 2.63 & 1.24 \\
\hline & $\mathbf{S}$ & 0.82 & 18.20 & 8.16 & 4.67 & 57.15 & 68.42 & 31.58 & 0.00 & 1.32 \\
\hline
\end{tabular}


Table.4 Micro-nutrients status in the soil of different blocks of Alirajpur district

\begin{tabular}{|c|c|c|c|c|c|c|c|c|c|c|}
\hline Locations & Parameter & Min & Max & Mean & SD & $\mathrm{CV}$ & PSD & PSM & PSH & NI \\
\hline \multirow[t]{5}{*}{ Alirajpur(n=83) } & $\mathbf{Z n}$ & 0.03 & 0.97 & 0.27 & 0.14 & 51.81 & 96.39 & 3.61 & 0.00 & 1.04 \\
\hline & $\mathbf{C u}$ & 0.09 & 3.74 & 0.96 & 0.92 & 95.56 & 8.43 & 28.92 & 62.65 & 2.54 \\
\hline & $\mathrm{Fe}$ & 1.55 & 25.54 & 7.55 & 4.92 & 65.20 & 32.53 & 39.76 & 27.71 & 1.95 \\
\hline & Mn & 1.34 & 42.00 & 12.34 & 8.77 & 71.05 & 0.00 & 8.43 & 91.57 & 2.92 \\
\hline & B & 0.03 & 4.43 & 1.91 & 1.16 & 60.85 & 18.07 & 8.43 & 73.49 & 2.55 \\
\hline \multirow[t]{5}{*}{$\operatorname{Bhabra}(\mathrm{n}=20)$} & $\mathbf{Z n}$ & 0.17 & 1.97 & 0.50 & 0.38 & 76.74 & 75.00 & 20.00 & 5.00 & 1.30 \\
\hline & $\mathrm{Cu}$ & 0.59 & 3.15 & 1.27 & 0.61 & 47.58 & 0.00 & 0.00 & 100.00 & 3.00 \\
\hline & $\mathbf{F e}$ & 3.65 & 35.00 & 19.53 & 8.46 & 43.31 & 1.20 & 1.20 & 90.00 & 2.85 \\
\hline & Mn & 4.58 & 43.00 & 26.64 & 12.08 & 45.35 & 0.00 & 0.00 & 100.00 & 3.00 \\
\hline & B & 0.45 & 2.88 & 1.42 & 0.86 & 60.25 & 1.20 & 10.84 & 50.00 & 2.45 \\
\hline \multirow[t]{5}{*}{ Jobat $(n=63)$} & $\mathbf{Z n}$ & 0.04 & 1.50 & 0.27 & 0.21 & 78.88 & 95.24 & 3.17 & 1.59 & 1.06 \\
\hline & $\mathrm{Cu}$ & 0.16 & 3.16 & 0.85 & 0.70 & 81.93 & 7.94 & 30.16 & 61.90 & 2.54 \\
\hline & $\mathbf{F e}$ & 1.43 & 36.00 & 9.20 & 6.98 & 75.83 & 25.40 & 36.51 & 38.10 & 2.13 \\
\hline & Mn & 2.49 & 38.94 & 12.17 & 8.22 & 67.56 & 0.00 & 6.35 & 93.65 & 2.94 \\
\hline & B & 0.05 & 4.76 & 1.02 & 1.08 & 106.17 & 47.62 & 20.63 & 31.75 & 1.84 \\
\hline \multirow[t]{5}{*}{ Kathiwara $(\mathrm{n}=30)$} & $\mathbf{Z n}$ & 0.05 & 1.13 & 0.25 & 0.22 & 90.24 & 93.33 & 6.67 & 0.00 & 1.07 \\
\hline & $\mathrm{Cu}$ & 0.06 & 2.55 & 0.48 & 0.50 & 102.74 & 20.00 & 43.33 & 36.67 & 2.17 \\
\hline & $\mathbf{F e}$ & 1.07 & 21.90 & 11.56 & 5.32 & 45.98 & 10.00 & 20.00 & 70.00 & 2.60 \\
\hline & Mn & 2.43 & 38.69 & 18.32 & 9.57 & 52.21 & 0.00 & 3.33 & 96.67 & 2.97 \\
\hline & $\mathbf{B}$ & 0.69 & 4.43 & 2.41 & 1.07 & 44.29 & 0.00 & 3.33 & 96.67 & 2.97 \\
\hline \multirow[t]{5}{*}{ Sondwa(n=38) } & $\mathbf{Z n}$ & 0.08 & 1.98 & 0.29 & 0.31 & 108.72 & 94.74 & 2.63 & 2.63 & 1.08 \\
\hline & $\mathrm{Cu}$ & 0.18 & 3.42 & 0.95 & 0.73 & 76.67 & 2.63 & 23.68 & 73.68 & 2.71 \\
\hline & $\mathbf{F e}$ & 1.33 & 16.15 & 6.04 & 3.94 & 65.11 & 47.37 & 28.95 & 23.68 & 1.76 \\
\hline & Mn & 1.97 & 35.85 & 10.02 & 8.53 & 85.19 & 0.00 & 23.68 & 76.32 & 2.76 \\
\hline & $\mathbf{B}$ & 0.64 & 3.64 & 2.07 & 0.78 & 37.60 & 0.00 & 7.89 & 92.11 & 2.92 \\
\hline \multirow[t]{5}{*}{ Udaigarh(n=38) } & $\mathbf{Z n}$ & 0.04 & 1.03 & 0.34 & 0.21 & 61.99 & 89.47 & 10.53 & 0.00 & 1.11 \\
\hline & $\mathrm{Cu}$ & 0.06 & 3.36 & 1.40 & 0.82 & 58.99 & 2.63 & 0.00 & 97.37 & 2.95 \\
\hline & $\mathrm{Fe}$ & 1.48 & 34.55 & 13.79 & 9.32 & 67.55 & 10.53 & 34.21 & 55.26 & 2.45 \\
\hline & Mn & 1.73 & 43.00 & 18.43 & 10.83 & 58.80 & 0.00 & 5.26 & 94.74 & 2.95 \\
\hline & B & 0.05 & 3.85 & 1.36 & 1.11 & 81.79 & 23.68 & 23.68 & 52.63 & 2.29 \\
\hline
\end{tabular}


Figure.1 Location map of study area

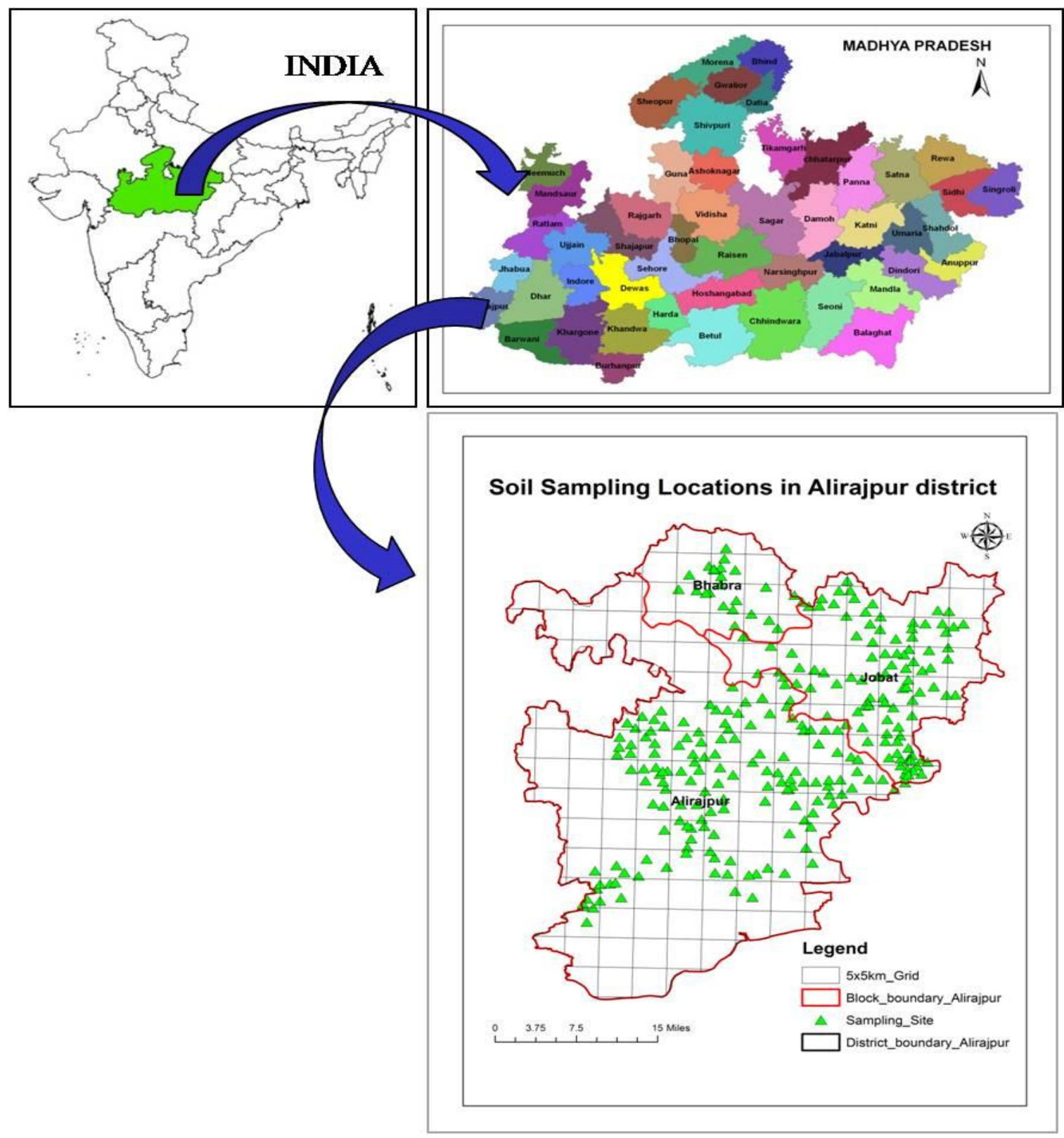




\section{Spatial variability of $\mathrm{pH}$ in soils of Alirajpur district of MP}

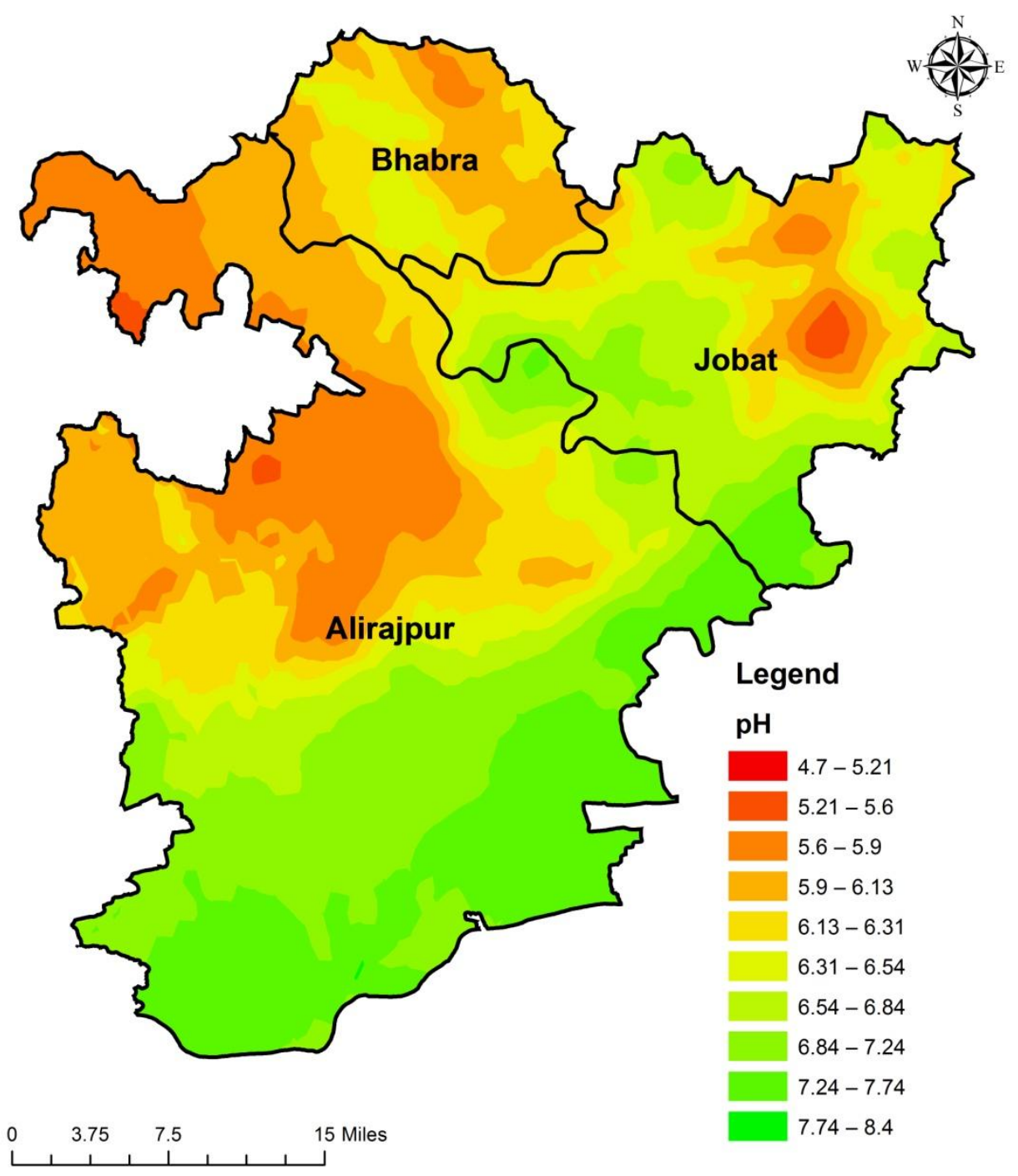




\section{Spatial variability of EC in soils of Alirajpur district of MP}

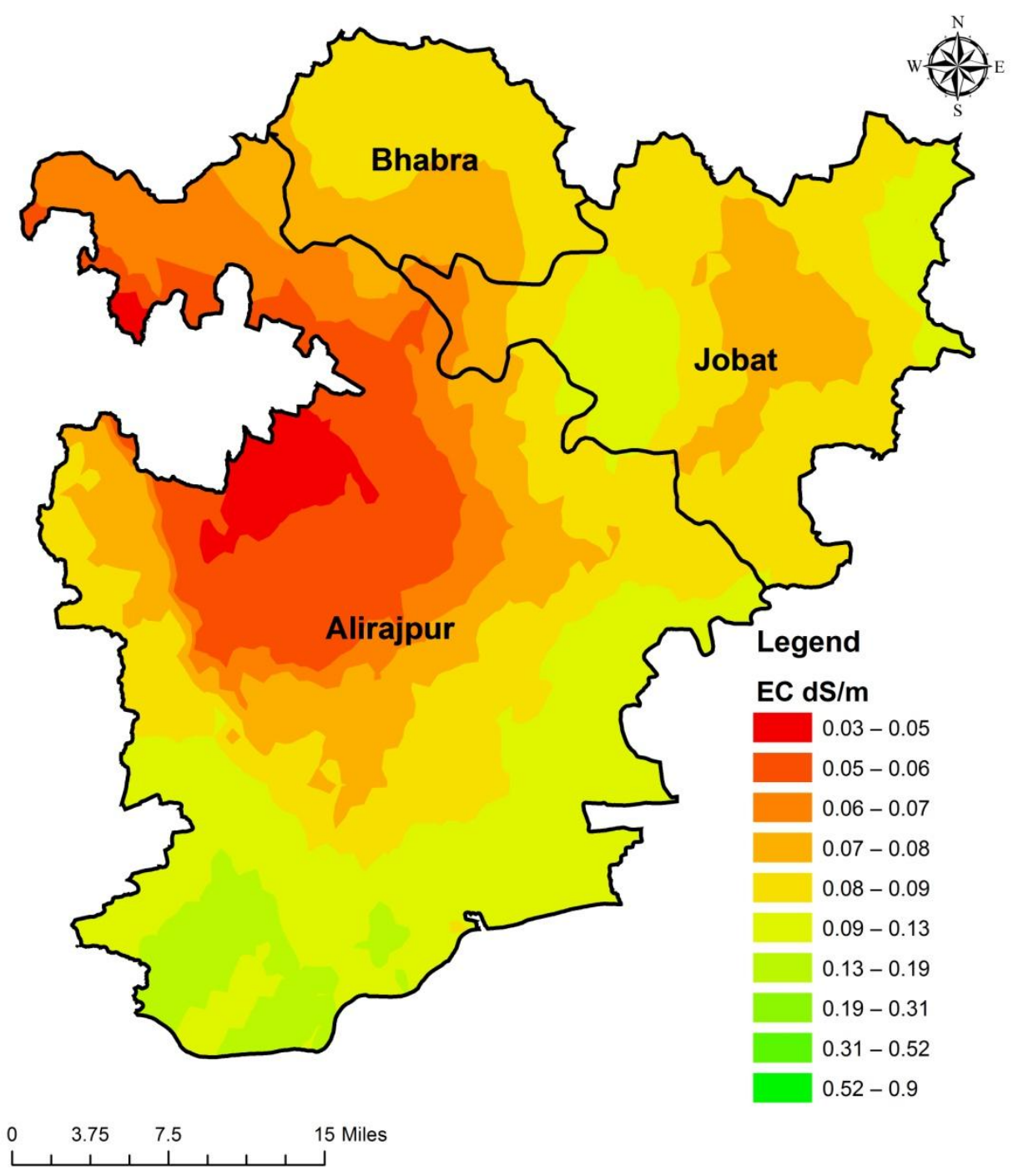




\section{Spatial variability of OC in soils of Alirajpur district of MP}

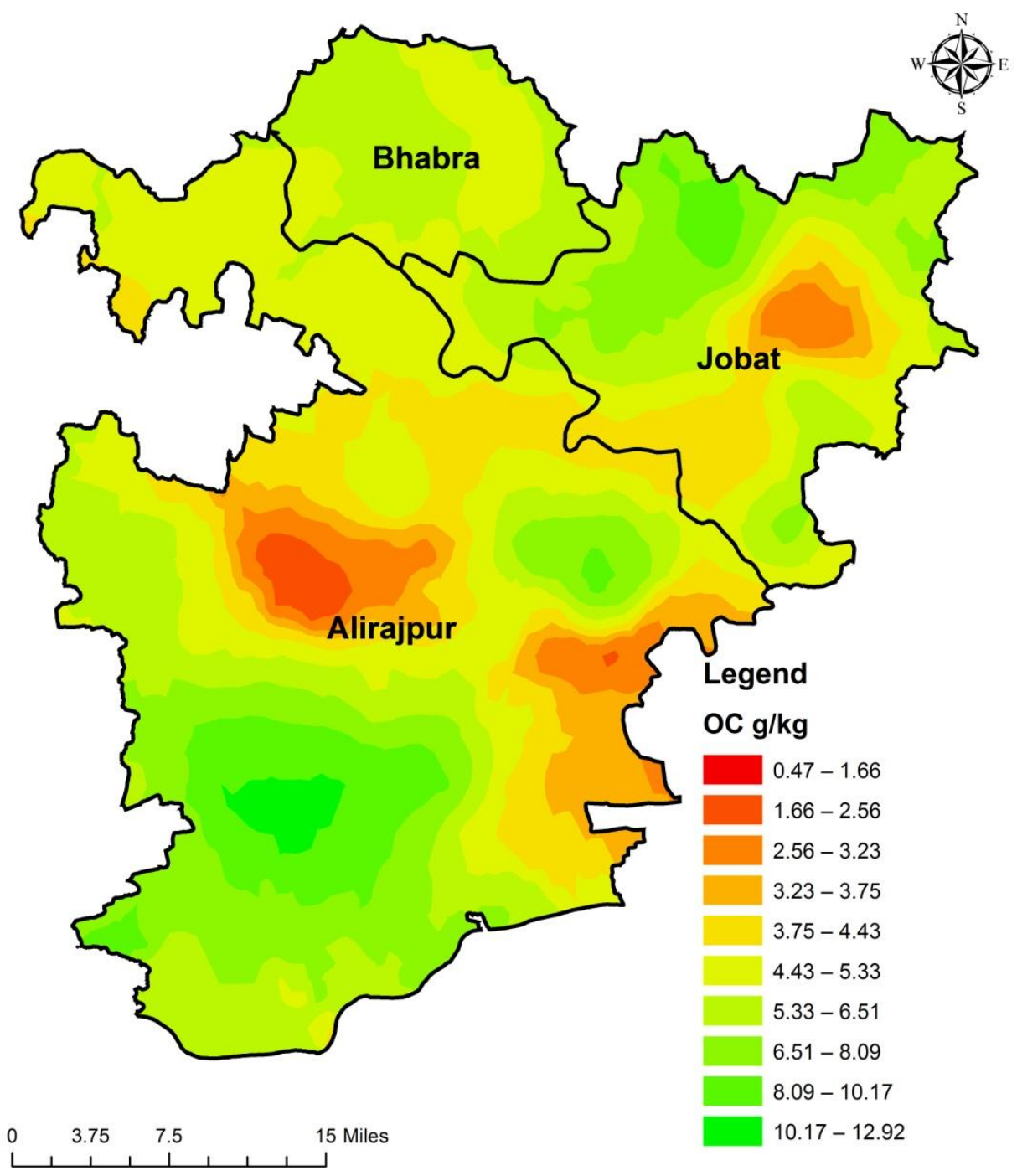




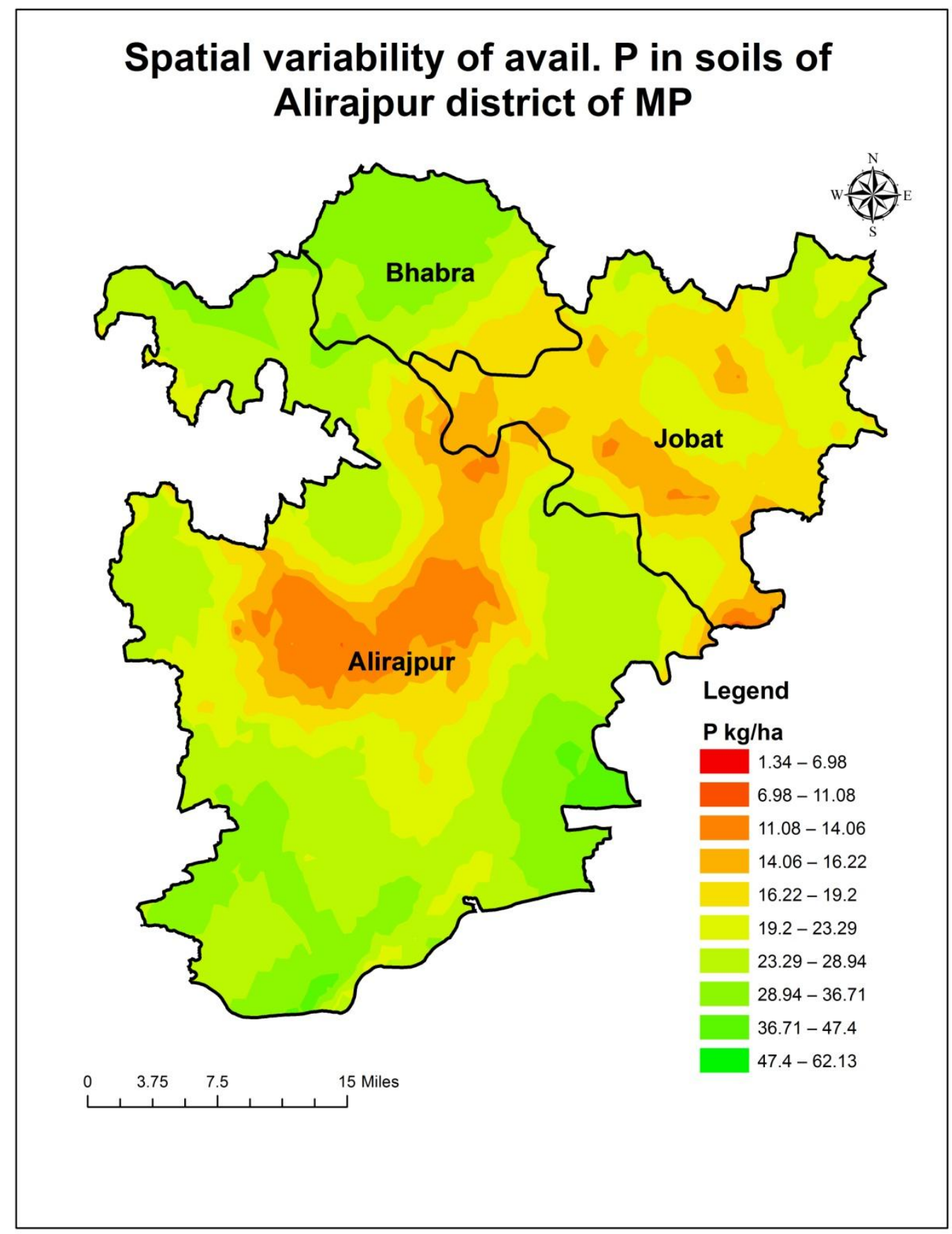




\section{Spatial variability of avail. $K$ in soils of Alirajpur district of MP}

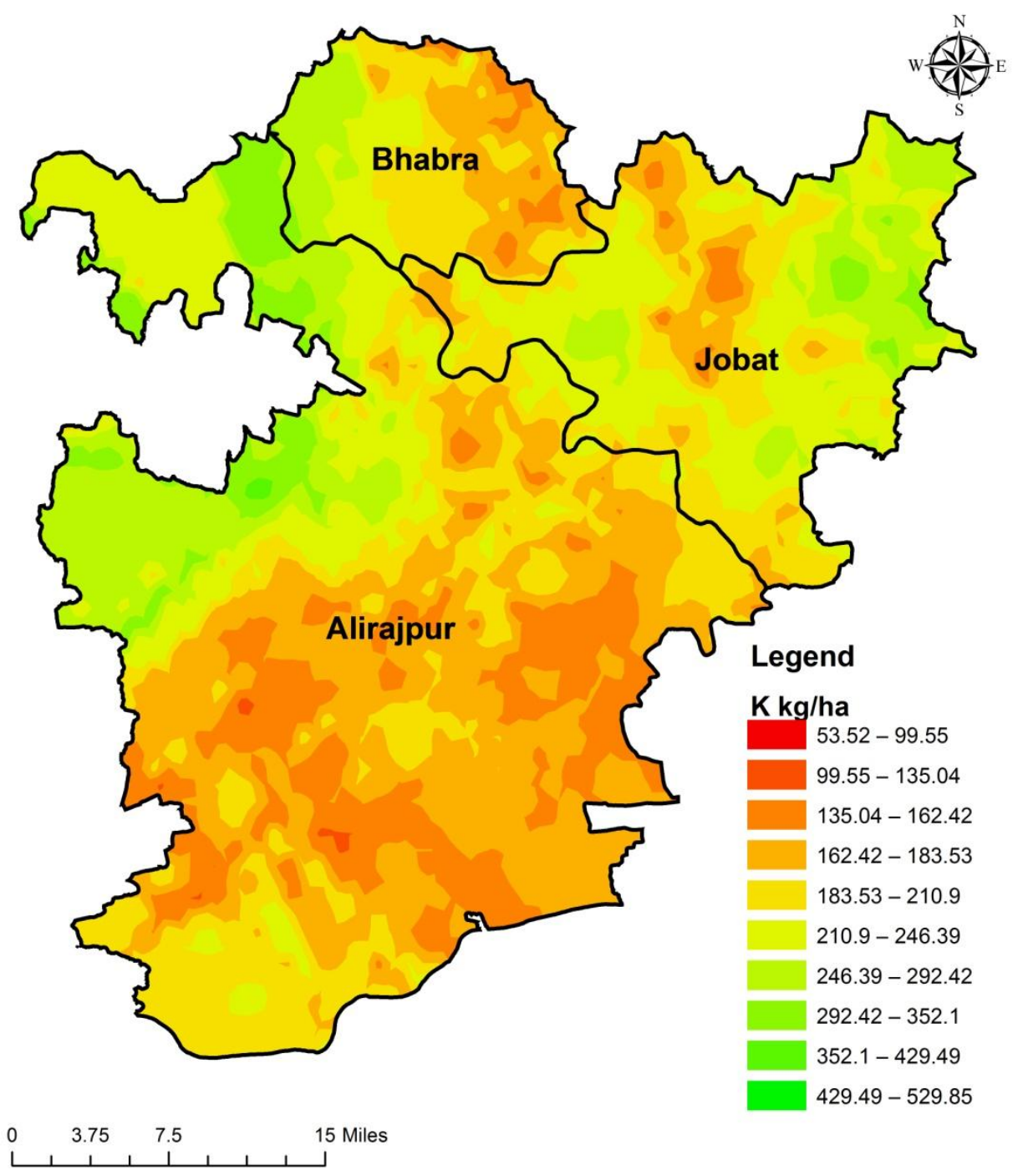




\section{Spatial variability of avail. S in soils of Alirajpur district of MP}

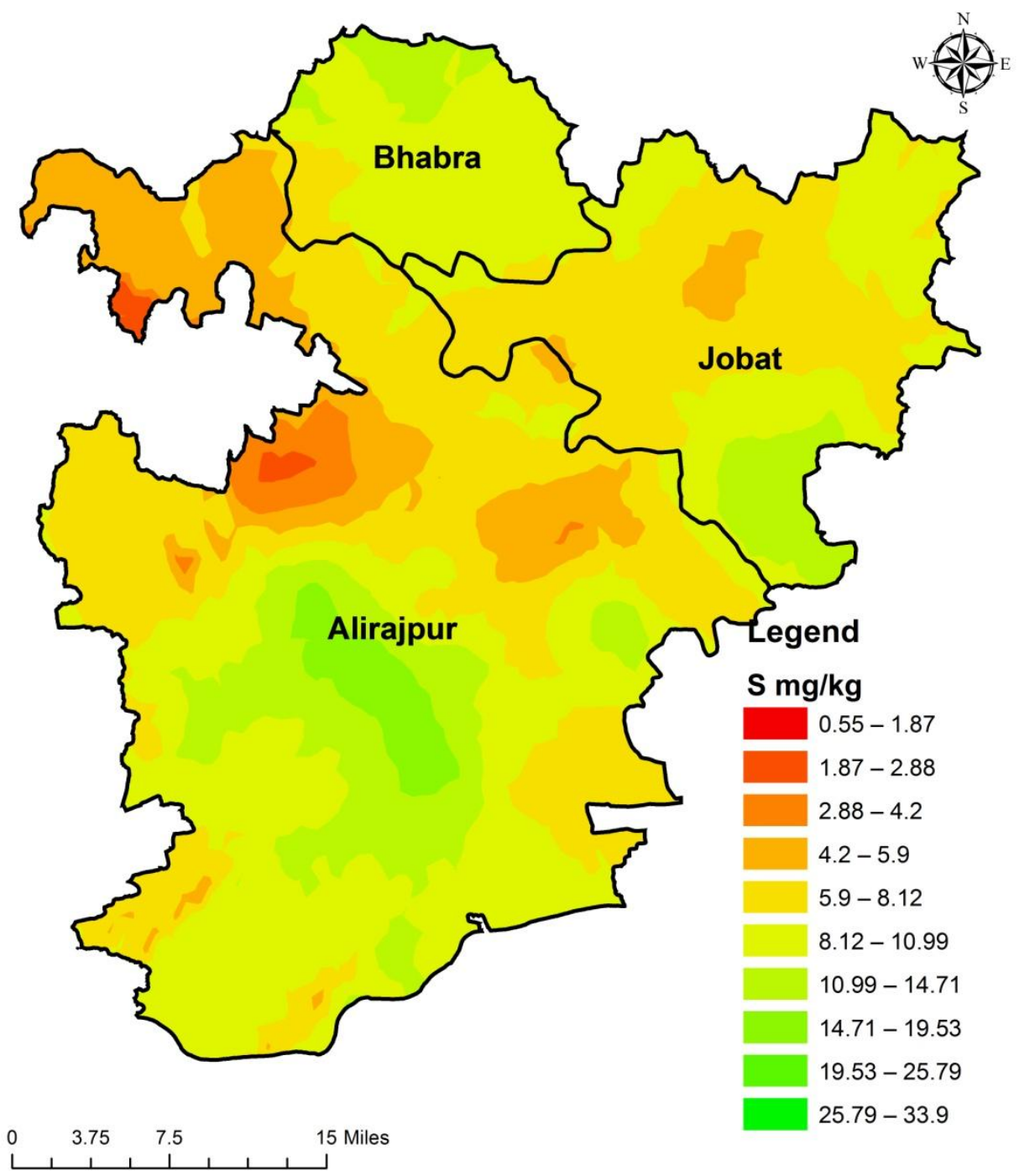




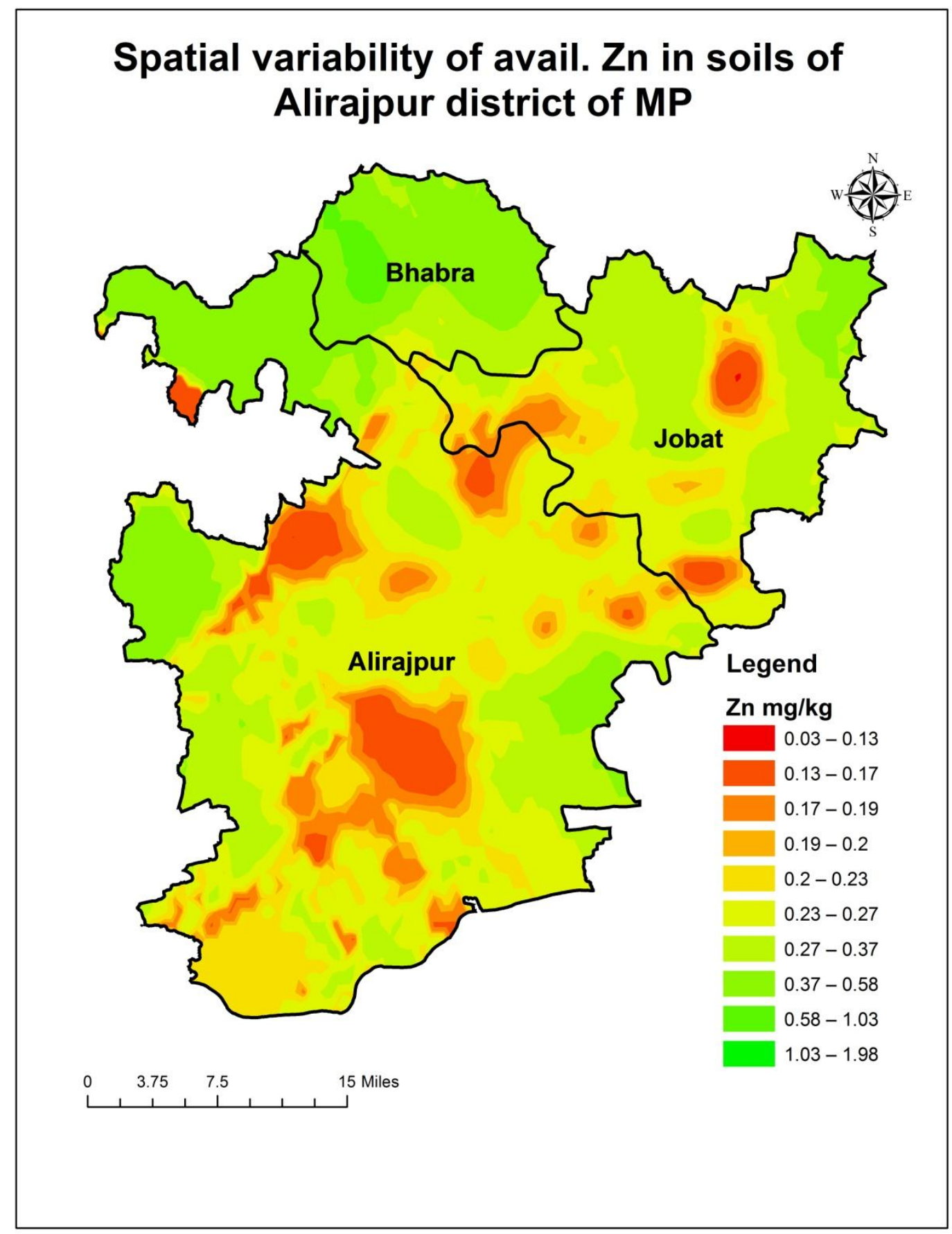




\section{Spatial variability of avail. Fe in soils of Alirajpur district of MP}

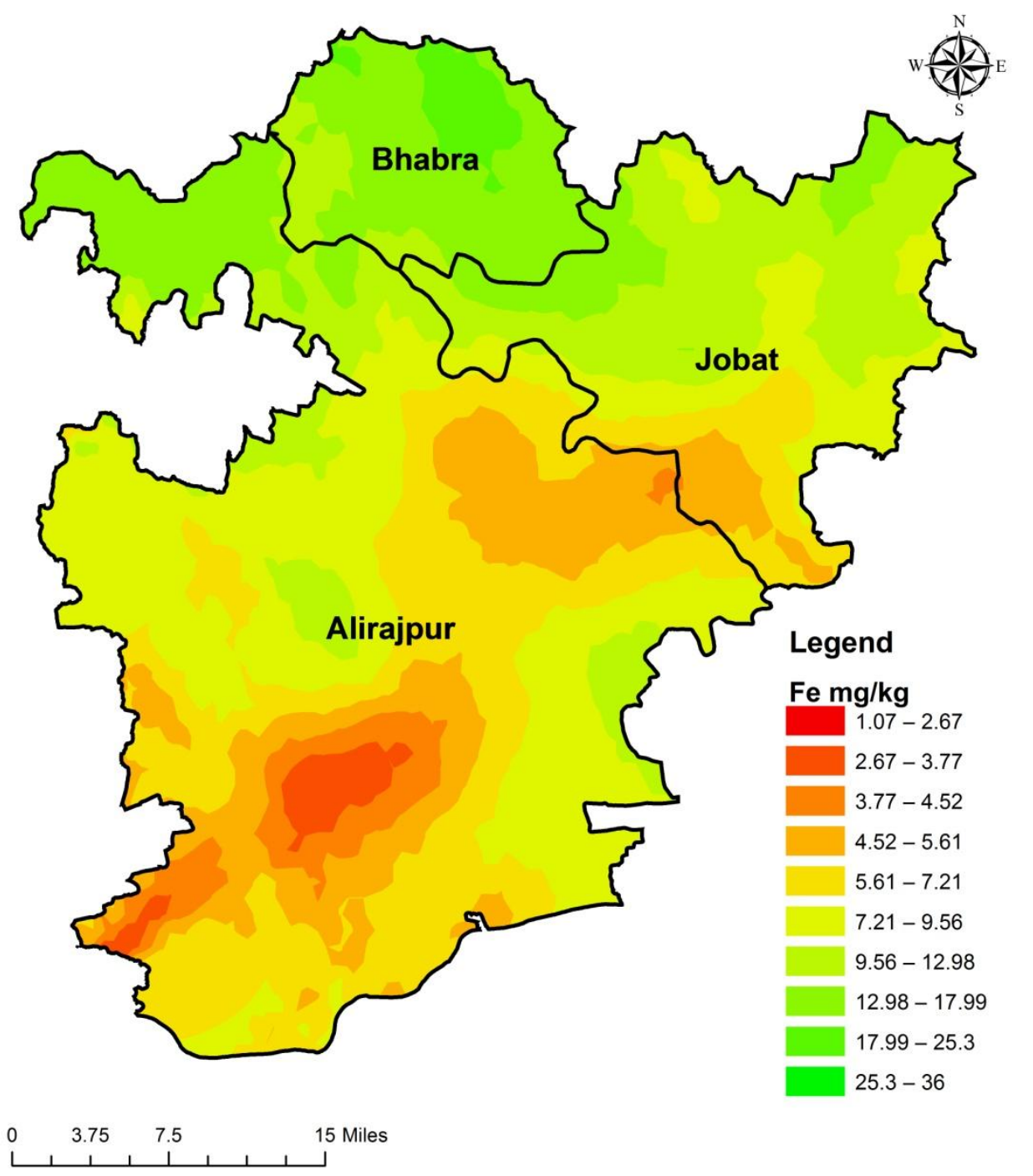




\section{Spatial variability of avail. $\mathrm{Cu}$ in soils of Alirajpur district of MP}

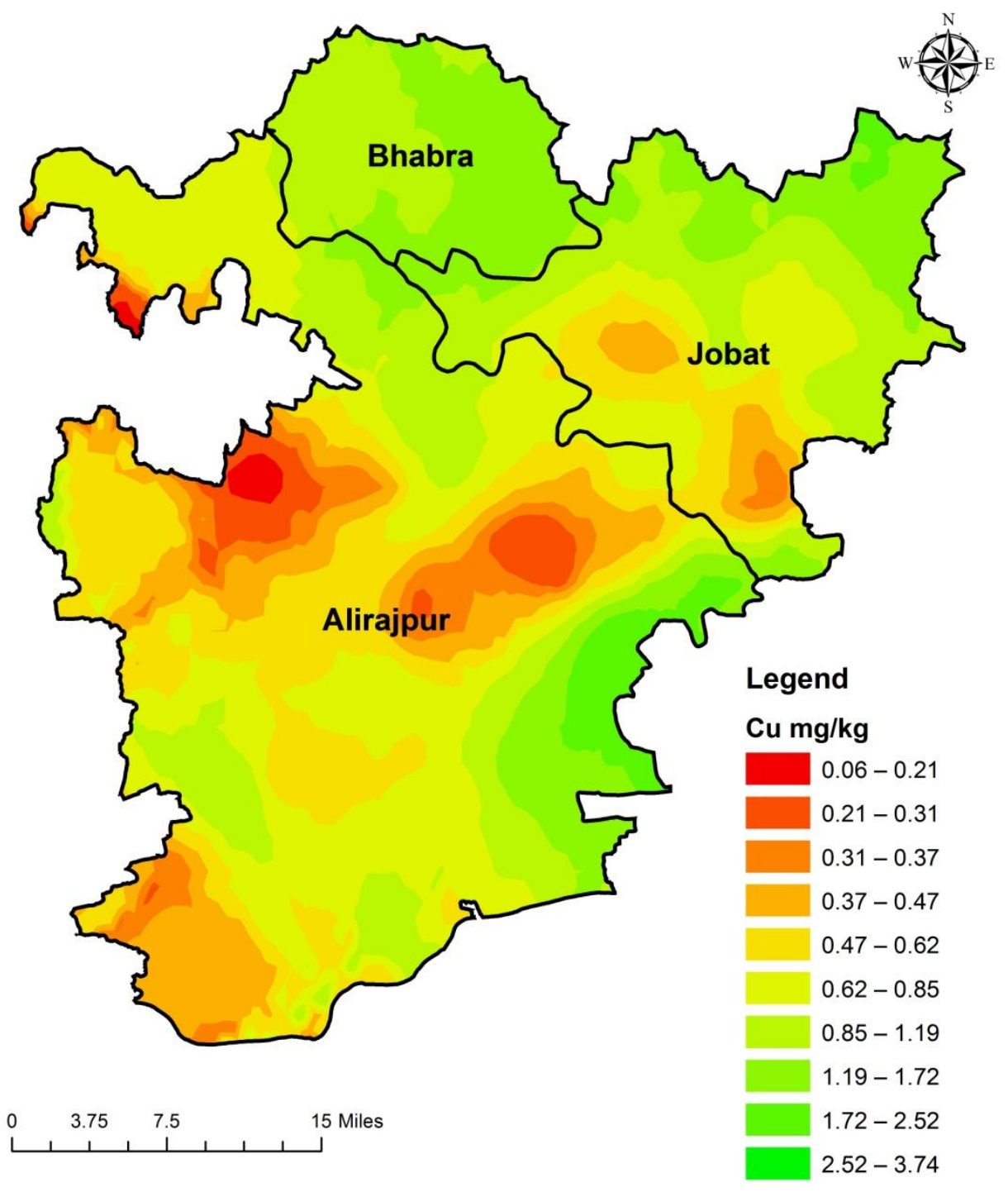




\section{Spatial variability of avail. Mn in soils of Alirajpur district of MP}

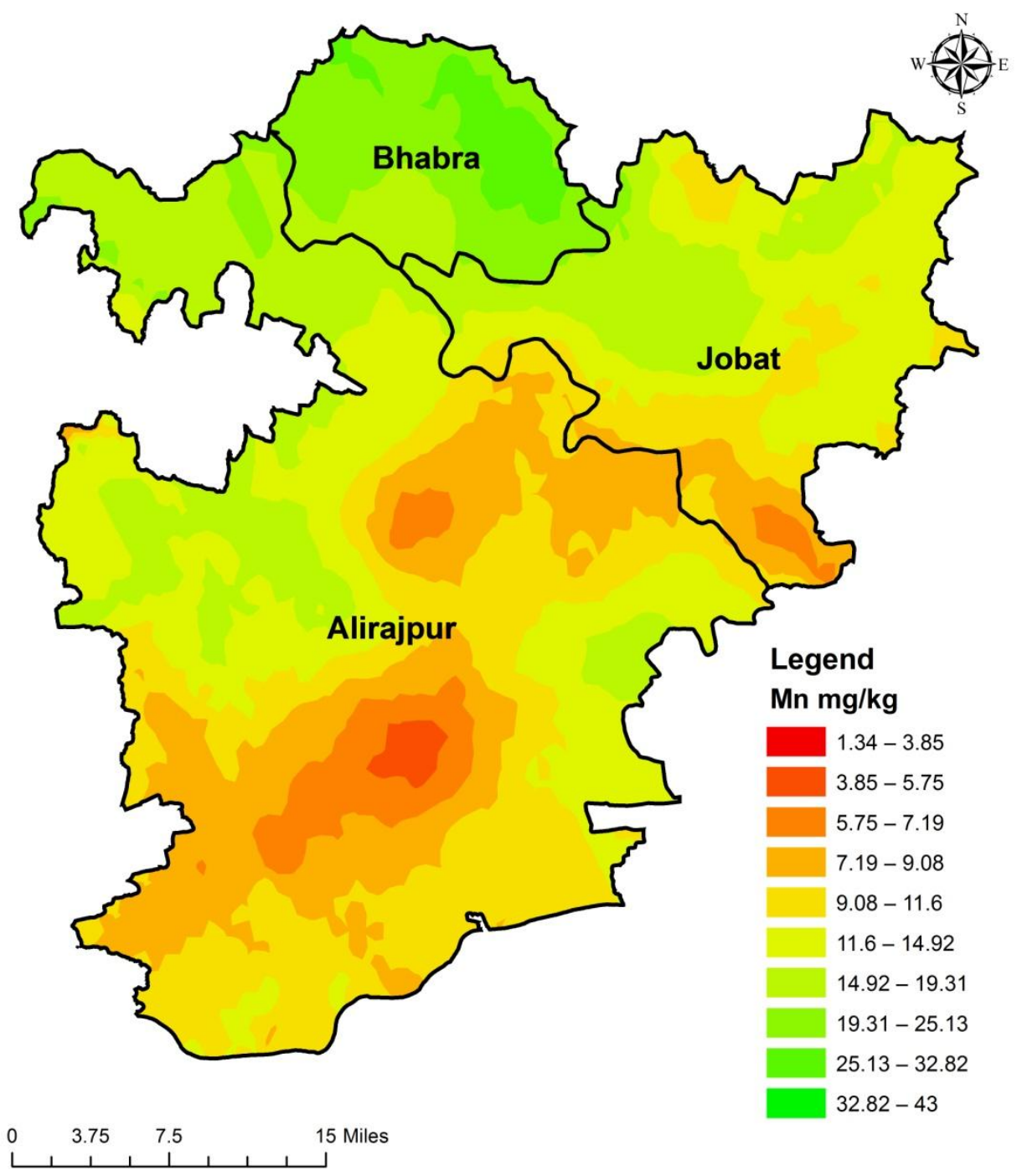




\section{Spatial variability of avail. B in soils of Alirajpur district of MP}

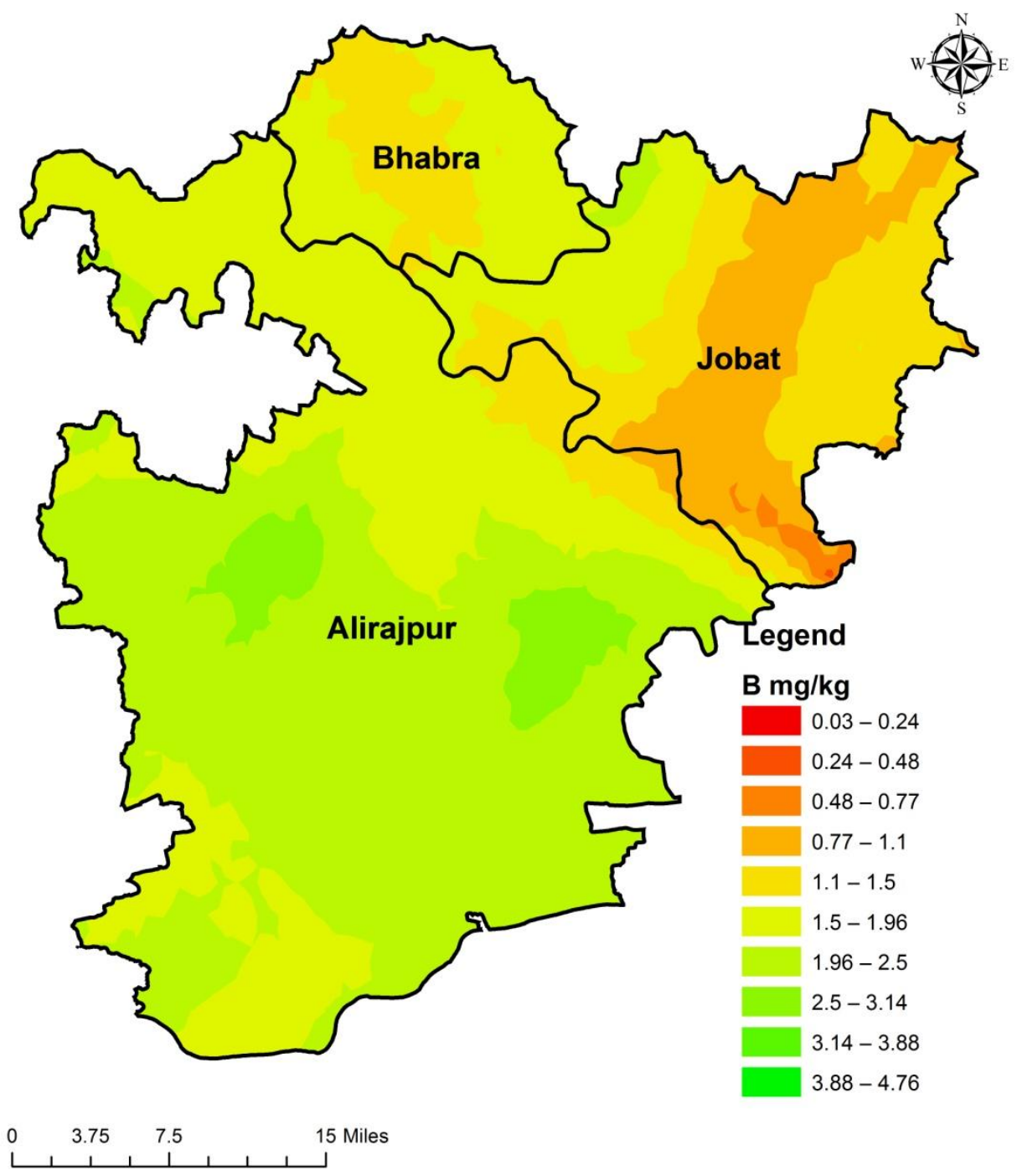


Status of available micro-nutrients and nutrient index in different block of Alirajpur district

Results relevant the status of available micronutrients $(\mathrm{Zn}, \mathrm{Cu}, \mathrm{Fe}, \mathrm{Mn}$, and $\mathrm{B})$ in the soil across different blocks of Alirajpur district showed variability in available $\mathrm{Zn}, \mathrm{Cu}, \mathrm{Fe}$, $\mathrm{Mn}$, and $\mathrm{B}$ to the extent of 0.03 to $1.98,0.06$ to $3.74,1.07$ to $36,1.34$ to 43 and 0.03 to 4.76 $\mathrm{mg} \mathrm{kg}{ }^{-1}$ with mean values of $0.30,0.96,9.92$, 14.54 and $1.67 \mathrm{mg} \mathrm{kg}^{-1}$, respectively. Results also showed that in Alirajpur district as whole 7.35 and $20.22 \%$ soil samples were tested low in $\mathrm{Cu}$ and $\mathrm{B}$, respectively but none of the soil sample was found deficient in Mn. It was also across Alirajpur, Bhabra, Jobat, Kathiwara, Sondwa and Udaigarh blocks of Alirajpur district variability in $\mathrm{Zn}, \mathrm{Cu}, \mathrm{Fe}, \mathrm{Mn}$ and $\mathrm{B}$ contents in the soil samples was 51.81, 76.74, $78.88,90.24,108.72$ and $61.99 ; 95.56,47.58$, $81.93,102.74,76.67$ and $58.99 ; 65.20,43.31$, $75.83,45.98,65.11$ and $67.55 ; 71.05,45.35$, 67.56, 52.21, 85.19 and 58.80 and 60.85, $60.25,106.17,44.29,37.60$ and 81.79 per cent, respectively. Micro-nutrients in the soil were moderately variable and none of the soil samples tested low in $\mathrm{Mn}$ and $\mathrm{Cu}$ hence these are not a major problem in Alirajpur district as a whole. The results are in good agreement with those reported by Thakre et al., (2013); Noor et al., (2013) and Zhang et al., (2014).

\section{Fertility maps of Alirajpur district}

Spatial variability maps of $\mathrm{pH}, \mathrm{EC}, \mathrm{SOC}$, $\mathrm{CaCO}_{3}$ and available $\mathrm{N}, \mathrm{P}, \mathrm{K}, \mathrm{S}, \mathrm{Zn}, \mathrm{Cu}, \mathrm{Fe}$, $\mathrm{Mn}$ and $\mathrm{B}$ was prepared employing geostatistical for which natural logarithmic transformation was used to reduce the skewness of the data distributions. Ordinary Kriging was chosen to create the spatial distribution maps of soil characteristics with the maximum search radius being set to the autocorrelation range of the corresponding variable. Semi-Variograms used for analysis of spatial distribution of above properties of soil. Results showed that no apparent anisotropy was found for any studied variable through variograms. Similar findings were also reported by Srinivasan and Poongothai (2013).

Conclusion in the present study is soils of Alirajpur district were found neutral to slightly acidic in reaction, safe in electrical conductivity, low to medium in organic carbon, non-calcareous in nature and extent of $\mathrm{N}, \mathrm{P}, \mathrm{K}, \mathrm{S}, \mathrm{Zn}, \mathrm{Cu}, \mathrm{Fe}$ and $\mathrm{B}$ deficiencies in soils samples were to the extent of 73.9, 26.1, $77.6,93.0,7.4,25.4$ and $20.2 \%$, respectively.

\section{Acknowledgment}

The authors are grateful to the Jawaharlal Nehru Krishi Vishwa vidhyalya, Jabalpur (M.P.), for sponsoring this research. The authors are also thankful to the Vice Chancellor, for providing the necessary facilities, Dr. H.K. RAI (Senior scientist \& Chairman, Department of Soil Science and Agricultural Chemistry) as well as my advisory committee, JNKVV, for his support and critical suggestions.

\section{References}

Andrews, S.S., Mitchell, J.P., Mancinelli, R., Karlen, D.L. and Hartz, T.K. 2002. OnFarm Assessment of Soil Quality in California's Central Valley. Agronomy Journal 94: 12-23.

Athokpam H, Wani SH, Kamei D, Athokpam HS, Nongmaithem J, Kumar D, Singh YK, Naorem BS, Thokchom RD, Devi L (2013). Soil macro- and micronutrient status of Senapati district, Manipur (India). Afr. J. Agric. Res. 8(39):49324936.

Baishya J and Sharma S. 2017. Analysis of physico-chemicals properties of soil under different land use system with 
special reference to agro ecosystem in Dimoria Development Block of Assam, India. International Journal of Scientific Research Education 5(6): 6526-6532.

Berger KC, Truog E (1939). Boron determination in soils and plants. Ind. Eng.Chem. Anal. Ed.11: 540-545.

Bharti V.S., Dotaniya M.L., Shukla S.P. and Yadav V.K. (2017) Managing soil fertility through microbes: prospects, challenges and future strategies. In: AgroEnvironmental Sustainability (Singh J.S., Seneviratne G.,eds.). Springer, pp 81-111. DOI 10.1007/9783-319-49724-2_5.

Cambule AH, Rossiter DG, Stoorvogel JJ, Smaling EMA (2014). Soil organic carbon stocks in the Limpopo National Park, Mozambique: amount, spatial distribution and uncertainty. Geoderma 213:46-56.

Cao SK, Chena KL, Cao GC, Zhang L, Ma J, Yang L, Lu BL, Chen L, Lu H (2011).The Analysis of Characteristic and Spatial Variability for Soil Organic Matter and Organic Carbon around Qinghai Lake. Procedia Env. Sci. 10:678-684.

Chesnin L, Yien CH (1951). TurbidImetric determination of available suiphates. Soil Sci. Soc. Am. Proc. 15:149-151.

Denton OA, Aduramigba VO, Ojo AO, Adeoyolanu OD, Are KS, Adelana AO, Oyedele AO, Adetayo AO and Oke AO. 2017. Assessment of spatial variability and mapping of soil properties for sustainable agricultural production using geographic information system techniques (GIS) Cogent Food \& Agriculture 3: 1-12.

Dilliwar P, Puri G, Singh R, Amule FC and Choudhary BK. 2014. To evaluate the soil quality of Kheri series under Jawaharlal Nehru Krishi Vishwa Vidyalaya soil of Maharajpur Farm. National conference on soil health: A key to unlock and sustain production potential September 3-4 2014 held at Department of Soil Science and Agricultural Chemistry, College of Agriculture, JNKVV, Jabalpur (M.P.).

Dubliya J. 2011. Soil health assessment of dusty acre farm under JNKVV, Jabalpur, Madhya Pradesh. M.Sc. Thesis, JNKVV, Jabalpur (M.P.).

Fraisse CW, Sudduth KA, Kitchen NR, Fridgen JJ (1999). Use of unsupervised clustering algorithms for delineating within Colfield management zones. ASAE Paper 993043, ASAE, Ontario, Canada.

Franzen, D.W., Hopkins, D.H., Sweeney, M.D., Ulmer, M.K. and Halvorson, A.D. 2002. Evaluation of soil survey scale for zone development of sitespecific nitrogen management. Journal of Agronomy 94: 381-384.

Hillel D (1980). Fundamentals of Soil Physics. Academic Press, Inc., New York.

Jackson ML (1973). Soil Chemical Analysis. Prentice Hall of India Pvt. Ltd., New Delhi.

Jha P and Mohapatra KP. 2012. Developing a Soil Quality Index for Ravinous Ustifluvents of the Semi-Arid Region of India. Journal of the Indian Society of Soil Science 60(2): 116-124.

Kumar P, Yadav BL, Raipur SG, Yadav B and Singh K. 2014. Status of major nutrients in relation to soil properties of Jaipur district of Rajasthan. Journal of Society of Soil and Water Conservation 13(1): 31-35.

Lindsay WL, Norvell WA (1978). Development of a DTPA soil test for $\mathrm{Zn}, \mathrm{Fe}, \mathrm{Mn}$ and $\mathrm{Cu}$. Soil Sci. Soc. Am. J. 42: 421-428.

Liu ZP, Shao MA, Wang YQ (2013). Spatial patterns of soil total nitrogen and soil total phosphorus across the entire Loess Plateau region of China. Geoderma 
197-198, 67-78.

Long, X.H., Zhao, J., Liu, Z.P., Rengel, Z., Liu, L., Shao, H.B. and Tao, Y. 2014. Applying geostatistics to determine the soil quality improvement by Jerusalem artichoke in coastal saline zone. Ecological Engineering 70: 319-326.

Mandal UK, Ramachandran K, Sharma K, Satyam B and Venkanna K. 2011. Assessing Soil Quality in a Semiarid Tropical Watershed Using a Geographic Information System. Soil Science Society of America Journal 75: 11441160 .

Maniyunda, L.M., Raji, B.A. and Gwari, M.G. 2013. Variability of some soil physicochemical properties on Lithosequence in Funtua, NorthWestern Nigeria. International Journal of Science and Research (IJSR), India Online ISSN: 2319-7064.

Meena, B.P., Tiwari, P.K., Dotaniya, M.L., Shirale, A.O. and Ramesh, K. (2017) Precision nutrient management techniques for enhancing nutrient use efficiency. In: Advances in nutrient dynamics in soil plant system for improving nutrient use efficiency (Elanchezhian, R., Biswas, A.K., Ramesh, K., Patra, A.K., eds), New India Publishing Agency, New Delhi, India. pp 61-74.

Muhr GR, Datta NP, Shankara SN, Dever F, Lecy VK Donahue RR (1963). Soil Testing in India. USAID Mission to India.

Noor YS and Shah Z. 2013. Spatial variability of micronutrients in citrus orchard of north western Pakistan Sarhad. J. Agric. 29(3).

Olorunlana FA. 2015. Factor analysis of soil spatial variability in Akoko region of Ondo state, Nigeria. Journal Geography and Regional Planning 8(1): 12-15.

Olsen SR, Cole CV, Vatanabe FS, Dean LA (1954). Estimation of available phosphorus in soil by extraction with sodium bicarbonate. Circ. U.S Dept. Agric. 939: 1-19.

Parker FW, Nelson WL, Winter Eric, Miller LE (1951). The broad interpretation of soil test informations. Agron. J. 43:105112.

Raghuwanshi DP, Tembhare BR and Gupta GP. 1992. Taxonomy of black and associated soils of Jabalpur, Pawarkheda and Indore Research Farms of M.P. JNKVV Research Journal 26: 12-14.

Ravikumar P and Somashekar RK. 2014. Spatial distribution of macronutrients in soils of Markandeya river basin, Belgaum, Karnataka, India. Proceedings of the International Academy of Ecology and Environmental Science 4(2): 81-94.

Ruffo ML, Bollero GA, Hoeft RG, Bullock DG (2005). Spatial variability of the Illinois soil nitrogen test: Implications for soil sampling. Agron. J. 97:14851492.

Sanyal SK, Dwivedi BS, Singh VK, Majumdar K, Datta SC, Pattanayak SK, Annapurna K (2015). Phosphorus in relation to dominant cropping sequences in India: chemistry, fertility relations and management options. Curr. Sci. 108:7-10.

Singh D, Chhonkar PK, Dwivedi BS (2007). Manual on Soil, Plant and Water Analysis Westville Publishing House, New Delhi.

Singh J and Dhaliwal NS. 2012. Distribution of DTPA-extractable and total micronutrients in association with properties of some reclaimed salt affected soils of southwest Punjab, India. An Asian Journal of Soil Science 7(1): 1-7.

Singh R, Puri G, Dilliwar P and Amule FC. 2014. Soil health assessment of Adhartal series under Jawaharlal Nehru 
Krishi Vishwa Vidyalaya. National conference on soil health: A key to unlock and sustain production potential September 3-4 2014 held at Department of Soil Science and Agricultural Chemistry, College of Agriculture, JNKVV, Jabalpur (M.P.).

Singh, R. (2017). Status of available sulphur and micronutrients in soils of Allahabad, Uttar Pradesh. Annals of Plant and Soil Research 19 (2): 237239.

Srinivasan and Poongothai. 2013. Soil nutrients with special health reference to zinc by using RS and GIS in and around Wellington reservoir, Tittagudi taluk, Cuddalore district, Tamilnadu, India. International Journal of Engineering Science Invention 2(5): 16.

Subbiah BV, Asija GL (1956). A rapid procedure for the determination of available nitrogen in soils. Curr. Sci. 25: 259-260.

Thakre YG, Choudhary MD and Raut RD. 2013. Available micronutrient cation status of red soils in Wardha region, India. Journal of Chemical and Pharmaceutical Research 5(8): 64-68.

Tomar VS. 1968. Studies on magnesium in Madhya Pradesh. M.Sc. Thesis, JNKVV, Jabalpur (M.P.).

Wang, J., Fu, B., Qiu, Y. and Chen, L. 2001. Soil nutrients in relation to land use and landscape position in the semi-arid small catchment on the loess plateau in China. Journal of Arid Environment 48: 537- 550.

Warkentin, B.P. and Fletcher, H.F. 1977. Soil quality for intensive agriculture. Proc Int Sem on Soil environ. and fert. Manage. Intensive Agriculture Society Science of Soil and Manure. National Institute of Agriculture Science, Tokyo, pp. 594-598.

Weindorf DC, Zhu Y (2010). Spatial variability of soil properties at Capulin Volcano, Mew Mexico, USA: implications for sampling strategy. Pedosphere 20:185-197.

Yang Y, Yang J (2005). The trend variability of soil organic matter content in the salinity region of Yucheng city in Shandong Province. Chin. J. Soil Sci. 36(5):647-651.

Yuan LB, Changc SX, Tiand L and Zhan Q. 2018. Conservation agriculture practices increase soil microbial biomass carbon and nitrogen in agricultural soils: A global meta-analysis. Soil Biology and Biochemistry, 121: 50-58.

Zhang YG, Zhang YY, Cai JP, Zhu P, Gao HJ and Jiang Y. 2014. Variation in available micronutrients in black soil after 30-year fertilization treatment. Plant and Soil Environment 60(9): 387393.

\section{How to cite this article:}

Tikam Chand Yadav, H.K. Rai, G.S.Tagore, Garima Padwar, Dayanidhi Chaubey and Divya Bhayal. 2018. GIS based Fertility Maps of Soils of Alirajpur District of Madhya Pradesh, India. Int.J.Curr.Microbiol.App.Sci. 7(12): 2088-2113. doi: https://doi.org/10.20546/ijcmas.2018.712.239 